\title{
YOUNG LEARNERS' PERCEPTIONS ON THE IMPLEMENTATION OF ONLINE ENGLISH PROFICIENCY TEST
}

\author{
Diah Royani Meisani ${ }^{1}$, Pupung Purnawarman ${ }^{2}$ \\ Doctoral Program in English Education, School of Postgraduate Studies, Universitas Pendidikan Indonesia, Jl. \\ DR. Setiabudi No.229 Bandung ${ }^{l}$ \\ Department of English Education, Faculty of Language and Literature Education, Universitas Pendidikan \\ Indonesia, Jl. DR. Setiabudi No.229 Bandung ${ }^{2}$ \\ diahroyani@student.upi.edu ${ }^{1}$,purnawarman@upi.edu ${ }^{2}$
}

\begin{abstract}
The present study made use of Cambridge Online English Test for Children and Young Learner to explore how young learners perceived the implementation of an online test and to what extent the ICT backgrounds and English exposures correlated to their online English test achievement. Three data collection strategies were used to gather the data that involved second to sixth-grade elementary school students as the participants. The instruments were: 1) Online English Proficiency Test for Young Learners; 2) observation field notes; and (3) interviews. The findings revealed that students' test scores diverse as their grade levels were also various. The mean score was 10.53 which could be categorized into Movers level which was in the middle level. It was also found that the three-quarter of the participants declared that they preferred having an online test as it gave them new experiences and comfortable feeling with taking a test on laptop or smartphones. From further investigation to the randomly selected six students, it was revealed three factors were majorly influential for young learners in benefitting the digital technology use. They were: 1) family socio-economic background;2) parental involvement in children's digital media use; and 3) learners' personal motivation in using the digital media.
\end{abstract}

Keywords: English for Young Learners; Online English Proficiency Tests; Young Learners.

DOI: 10.15642/NOBEL.2019.10.1.71-86

The voluminous exposure to digital technologies has resulted in the development of the younger generation to be able to seize technology better than their parents, who migrated to the digital world. This generation is often called as 'Digital Natives' or 'Net Generation' for they were born in a world where digital and online technologies have been an integral part of life - they have the capabilities of integrating new media into their daily lives and are bounded by opportunities to involve in new, technology-mediated forms of social engagement (Miller, 2017; Australians \& Smith, 2012; Killian, 2011; Bittman et al., 2011; Zevenbergen, 2007; Prensky, 2001). It has been a common assumption to consider our young learners have higher Information and Communication Technology (ICT) competency than their teachers or parents (Guo et al., 2008). However, it is still arguable whether or not good access can guarantee the regular, competent and rewarding use assumed by the Digital Native rhetoric (Australians \& Smith, 2012; Guo, 2008). 
Studies conducted by the Australian Bureau of Statistics in 2009 have proved that households with children under the age of 15 reached the access rate of $86 \%$. This percentage was higher than those in childless households who stood at $66 \%$. The data showed that more than half of all Australian children have been online by the time they entered primary school (aged 5-8). In the age of 12-14, when they enter high school nearly all have done so (Australians \& Smith, 2012). The data are linear with the results found by Kurnia \& Astuti (2017) that in the Indonesian context, teens or students topped the participants' list at $29.55 \%$ as the internet users compared to university students, citizens, parents, teachers/lecturers, communities and mass organizations, researchers, etc. The researchers assumed that young people are considered the most vulnerable to hoaxes. This group of participants is seen as the largest group of potential digital literacy agents. This is potentially affected by the roles of schools that are the most active partners in organizing digital literacy activities $(32.07 \%)$, followed by the government $(18.86 \%)$ and community $(11.94 \%)$. The community here might involve the role of the family in introducing digital knowledge to kids. Then, when seeing the data from this survey, age can be considered the key factor in the use of internet access (Williams et al., 2016).

Though, it should be pointed out that digital literacy does not merely deal with age, hardware possession, or how long a person spends time to computer and access internet (Guo et al., 2008; Reed and Giessler, 2002). Miller (2017) and Guo et al. (2008) also have taken a different angle on age and ICT competency, arguing that exposure to technology does not automatically affect the way students use technology or the way they learn best. In making this claim, they drew on research suggesting that explicit formal teaching to digital literacy is needed because growing up in the digital age is not a guarantee that learners are able to effectively leverage technology for research, collaboration, and content creation. These arguments are positively correlated to the definition of being digitally literate given by Kurnia \& Astuti (2017) and ICT Literacy Panel (2002). To become digitally literate, a person should possess the ability to use digital technology, communications tools, and/or networks to access, manage, integrate, evaluate, and create information in order to function in a knowledge society. Australians \& Smith (2012) adds by formulating the capacities young people develop for internet use that involve five elements, they are the quality and context of internet access, the frequency, duration, motivations, and purposes of their use, and their perceptions of its impact. Furthermore, a framework upon which the behaviors of the digital learners could be characterized is formulated by Teo (2013) that involve four categories: they 
grow up with technology, they are comfortable with multitasking, they are reliant on graphics, and they thrive on gratification.

Referring to recommendations made by Miller (2017) and Guo et al. (2008) about formal training to technology, ICT experience can be given to students through technologybased assessment-it can be a computer-based or web-based or online test. Chapelle (2003) encourages the use of the technology-based test as it offers new opportunities to realize some of the current ideals for interactive language assessment by providing the test takers information about their language ability at their convenience. As a viable alternative to paperand-pencil testing, a technology-based test has been a broad-based production that encompasses a large variety of assessment types, purposes, test delivery designs, and item types appropriated for wide-ranging areas that cover educational accountability and achievement testing, college and graduate admission testing, professional certification and licensure testing, psychological testing, intelligence testing, language testing, employment testing, adult education, and military use (Luecht \& Sireci, (2011). Friedrich (2008) and Alabi, Issa, \& Oyekunle (2012) support by stating that these types of testing allow the users to write, organize, deliver, and report on tests or surveys. Besides providing results more quickly than the paper-based testing, computer-based testing or web-based testing enable someone who has minimal or no previous computer experience to take the test as it commonly provides instruction tutorials before the examination begins.

Previous studies have indicated that technology-based testing in K-12 settings brings potential benefits as mentioned above (Alabi, Issa, \& Oyekunle, 2012; Luecht \& Sireci, 2011; Friedrich, 2008; Way, Davis, \& Fitzpatrick, 2006; Chapelle, 2003). Moreover, as the data from previous surveys signpost students' positive responses towards this kind of test (Way, Davis, \& Fitzpatrick, 2006), the present study aims at exploring whether those affirmative reactions also occur in the Indonesian context, particularly to elementary school students. Thus, to link the gap in the literature, this study is intended to investigate elementary school students'first experiences in taking an online English proficiency test and examining if their ICT competence contributes to English language skills or vice versa.

Regarding the above-mentioned issues, this study investigated elementary school students' ICT-related activities both at school and at home, and their perceptions towards the online English Proficiency Test after taking it for the first time. Four research questions were formulated in the following: (i) What ICT-related activities have the participants been engaged in at school and at home? (ii) What are the participants' English qualification levels measured by Cambridge Online English Test for Children and Young Learner? (iii) How do 
participants perceive the online test? (iv) To what extent the patterns of ICT-related activities at school and at home correlate with their achievement in the online test?

\section{METHODS}

\section{Participants}

Demographically, the study was conducted with 17 young learners aged from 7 to 12 years old who study at the elementary school varied from Grade 2 to 6 . Five of them were male and 12 of them were female. Ten students study in Malang City, three in Batu City, and five in Pamekasan Regency, Madura Island. The recruitment was conducted by giving direct offering to the targeted participants who fulfilled the following criteria: 1) they had English subject at school; 2) they had not done a kind of online test before; 3) they participated in the study with the permission of their parents; and 4) they themselves agreed to be the participants. All of the participants' parents were given detailed information about the test and what their kids did in the tests. The test was then conducted after gaining parents' oral approval for their kids' participation and the kids' own agreement to join the study.

\section{Instrumentation}

As mentioned before, three instruments were used to collect the data. Each of the instruments is explained as follows.

\section{Online English Proficiency Test for Young Learners}

The online English test in this study was taken from Cambridge Online English Test for Children and Young Learners that can be accessed through the link http://www.cambridgeenglish.org/test-your-english/young-learners/. The test used in this present study is a quick free online test for children aged $7-12$ that consists of 20 multiple choice questions and is divided into four parts covering listening for Part 1 and 2, and Reading and Writing for Part $3 \& 4$. This is authored and published by the University of Cambridge ESOL Examinations (UCLES). This takes more or less 40 minutes for the test takers to do the test and immediate results appear right after the test finishes showing which Cambridge English qualification might be best for them. The test spans three ability levels: Starters, Movers, and Flyers. Starters are at a level equivalent to pre-A1 of Common European Framework of Reference for Languages (CEFR), Movers are at A1, and Flyers are equivalent to A2.

As it is a web-based test, software installation is not needed. The test is delivered through internet technology and can be accessed through multiple platforms in Personal Computer (PC), laptop, or smartphones (Gupta, 2018). Similar to Computer-Based Testing 
(CBT), a web-based test is one specific form of Information and Communication Technology (ICT) for assessment to administer tests in which the responses are electronically recorded, assessed, or both (Alabi, Issa, \& Oyekunle, 2012).

The websites of Cambridge Assessment English are accessible to all internet users. The main website accessibility standards are well-maintained so that the accessibility and usability levels of the sites are good (UCLES). To support the websites, the following features are used: 1) the pages are designed with a minimum screen resolution of $1024 \times 768$ pixels; 2) page structure is conveyed using header elements; 3) a style sheet is used with relative font sizes on all text with the exception of graphical text; 4) information can still be accessed if style sheets are turned off or not supported; 5) text can be increased or decreased in size by using the "view" option in your browser; 6) images that convey important information have alternative text - if an image is used for a decorative purpose the alternative text will be left blank; 7) no information is exclusively conveyed using color; and 8) a site map is available to provide information about the structure of the website (http://www.cambridgeenglish.org).

In this study, participants did the test on a laptop or on smartphones provided by the researcher. The participants did the test at school after school hours, accompanied by their parents or caregivers. Permission was also obtained from the school to conduct the test to some of their students after school. Simply by clicking start, the participants could begin the test and answer the multiple-choice questions. The listening component contained two parts each with five items. The parts were based on dialogues between an adult and a child where the dialogues were increasingly complex with each subsequent part, and from one test level to another. In Listening Part 1, the students chose pictures that identified the content of a dialogue. In Listening Part 2, students had to drag the answers and placed them onto the pictures based on the dialogue. Similar to the Listening section, the Reading and Writing Section had two parts each with five items. In this part, students chose a grammatically correct option for gaps in a reading text and complete the conversation between an adult and a child in order to measure their comprehension of connected text, knowledge of social expressions, as well as verb number, tense, and contracted forms of modal verbs (Bailey, 2005).

\section{Observation field notes}

As this study was intended to investigate how young learners conducted the online English proficiency test, observation field notes were used to gather the data that captured attitudes, 
direct responses, and challenges that students faced as the first-timers during taking the online test.

\section{Interviews}

As one of the practical ways of gathering information on participants' digital literacy experiences, semi-structured interview format was used to understand the personal experiences of each participant as it provides some consistency between interviews while allowing each participant the opportunity to share new perspectives that may not have been asked about directly (Bangou \& Waterhouse, 2008). The interviews covered four themes: participants' demographic information, English class at school, their ICT-related activities at school and at home, and their perceptions towards the online test. While the interviews were conducted, voice recorder was used to record the participants' responses. The interviews were conducted right after each student finished doing the test. As the parents and caregivers accompanied the children during the interviews, further elucidations about children's ICT backgrounds and English activities they had been engaged in were directly conducted to parent and/or caregivers after the sessions with the students accomplished.

\section{RESULTS AND DISCUSSIONS}

\section{ICT-Related Activities}

The data gathered from the interviews were addressed to know the activities that the participants were engaged in related to ICT. All the participants $(n=17)$ were asked about their ICT-related activities at school-whether or not they had the ICT subject, what they learned in ICT class, and the hardware used in ICT class. Besides, their home ICT-related activities were also investigated. The data showed that all students studied in Batu City had ICT Class at school. There were only two students from Malang City and four participants whose school was located in Pamekasan Regency, Madura Island, that did not learn ICT as the school did not provide the subject.

In Indonesian Elementary School Curriculum, ICT Subject is included as a local content subject. As a consequence, it is a bottom-up policy in which the school may initiate the composition of the local subjects in the curriculum and decide to what grade levels the subject is given (Alwasilah, 2013). When seeing the data in Table 2 in the following section, it is identified the length of time the students learn ICT subject formally vary between one and another. The students in the higher grade level, by all means, have more chances of learning the subject. However, it does not directly determine that their ICT competency is better than the others who have it later. From the data, it is recognized that six students did 
not formally receive education on ICT. Others have gained ICT subject in the various length of time: 1 year (4 students), 2 years (3 students), 3 years (1 students), and 4 years (3 students). This different span of time occurs due to students' different grade levels and each school policy in deciding from what grade the ICT subject is given.

Furthermore, in the interview, students who admitted that they had ICT subject at school explained that they learned about the parts of the computer hardware and their functions. For the software skills, the data showed that the students also learned simple tasks, like how to use Word Pad, Paint, how to create tables and frames. This has fulfilled the lowest level of digital literacy which is digital competence mastery of basic skills and competence proposed by McLoughlin (2011) that is considered fit young learners' digital literacy learning objectives.

Besides having formal education on ICT, the participants were also exposed to and engaged in ICT related activities at home. In terms of hardware possession, all confessed that they were familiar with smartphones and internet use. All of them used smartphones for having the internet applications and only five of them used a laptop and/or Personal Computer (PC) besides smartphones at home. Among the internet applications provided in smartphones, gaming was the mostly done by the participants $(88.24 \%)$, followed by using social media (Facebook, Whatsapp, Instagram etc.) and downloading music and videos that reached the same percentage (64.71\%), searching information on Google for school and others $(41.18 \%)$ and reading e-book which was the least of all (17.65\%). From this information, it can be implied that the participants have been possessing the basic skills and competence of ICT as suggested by McLoughlin (2011). Thus, in doing the online test, data from the observation field notes show that there were no substantial challenges faced by the participants although that was the first time for them to do an online test. Questions from the participants were meant to be verifications than inquiries, to make sure that they had done the right procedures in the test. In this case, the researcher who accompanied the participants during the test while observing them was not allowed to give any information when the participants were having the test as the procedures of doing the test were explained before they clicked 'start'.

\section{English Test Results}

All of the participants $(n=17)$ were willing to take the Cambridge Online Test for Young Learners. It was the first experience for all of them to take a kind of online test. The test results showed a varied range of scores of the students who were also diverse in grade levels. 
As Cambridge Online test span three qualification levels which are Starters, Movers, and Flyers, the students' scores were categorized based on those levels. The table below displays the range scores for Starters to Flyers.

Table 1. Participants' Cambridge English Qualification Levels

\begin{tabular}{clc}
\hline Range Scores & \multicolumn{1}{c}{$\begin{array}{c}\text { English Qualification } \\
\text { Levels }\end{array}$} & $\begin{array}{c}\text { Number of Participants } \\
\text { in Each Level }\end{array}$ \\
\hline $0-7$ & Starters & 7 \\
$8-10$ & Starters/Movers & 3 \\
$11-14$ & Movers & 1 \\
$15-17$ & Movers/Flyers & 3 \\
$18-20$ & Flyers & 3 \\
\hline
\end{tabular}

From the table above, it can be seen that the test divided the participants into five qualification levels from Starters to Flyers. It shows that the dominant number is on Starters Level. Furthermore, from two ranges of scores $(8-10$ and $15-17)$ students could be recommended to be included in one of the two level options $-8-10$ for Starters/Movers and 15 - 17 for Movers of Flyers. In this case, teachers' recommendations are needed to determine which level is more appropriate for those students when the test is used for other particular purposes.

As the participating students consisted of two, three, four, five, and six graders, classifications towards students' test scores based on their grade levels might be needed to give another point of view. The table below presents each student' score along with other related information of students' formal ICT and English learning.

Table 2. Participants' Test Scores

\begin{tabular}{|c|c|c|c|c|c|c|c|}
\hline \multirow[t]{2}{*}{ Participant } & \multirow[t]{2}{*}{ Gender } & \multirow[t]{2}{*}{ Grade } & \multirow[t]{2}{*}{ Score } & \multirow{2}{*}{$\begin{array}{c}\text { Cambridge } \\
\text { English } \\
\text { Qualification }\end{array}$} & \multicolumn{2}{|c|}{$\begin{array}{l}\text { Year(s) of Learning } \\
\text { the Subject at School }\end{array}$} & \multirow{2}{*}{$\begin{array}{c}\text { Preference of } \\
\text { Online Test or } \\
\text { PBT }\end{array}$} \\
\hline & & & & & English & ICT & \\
\hline Student 1 & $\mathrm{~F}$ & 2 & 6 & Starters & 1 & 1 & PBT \\
\hline Student 2 & $\mathrm{~F}$ & 2 & 7 & Starters & 1 & 1 & PBT \\
\hline Student 3 & M & 2 & 7 & Starters & 2 & 2 & Online Test \\
\hline Student 4 & $\mathrm{~F}$ & 2 & 19 & Flyers & 1 & 1 & Online Test \\
\hline Student 5 & $\mathrm{~F}$ & 2 & 0 & Starters & 1 & 1 & PBT \\
\hline Student 6 & M & 2 & 6 & Starters & 2 & 0 & Online Test \\
\hline Student 7 & $\mathrm{~F}$ & 3 & 4 & Starters & 2 & 0 & Online Test \\
\hline Student 8 & $\mathrm{~F}$ & 4 & 10 & Starters/Movers & 4 & 2 & Online Test \\
\hline Student 9 & M & 4 & 10 & Starters/Movers & 4 & 2 & Online Test \\
\hline Student 10 & M & 5 & 17 & Movers/Flyers & 5 & 4 & Online Test \\
\hline Student 11 & $\mathrm{~F}$ & 5 & 8 & Starters/Movers & 5 & 4 & Online Test \\
\hline Student 12 & $\mathrm{~F}$ & 5 & 11 & Movers & 3 & 0 & PBT \\
\hline Student 13 & $\mathrm{~F}$ & 6 & 7 & Starters & 6 & 3 & Online Test \\
\hline Student 14 & $\mathrm{~F}$ & 6 & 16 & Movers/Flyers & 4 & 0 & PBT \\
\hline Student 15 & M & 6 & 18 & Flyers & 6 & 4 & Online Test \\
\hline Student 16 & $\mathrm{~F}$ & 6 & 18 & Flyers & 4 & 0 & Online Test \\
\hline Student 17 & $\mathrm{~F}$ & 6 & 15 & Movers/Flyers & 4 & 0 & PBT \\
\hline Mean & & & 10.53 & Movers & & & \\
\hline
\end{tabular}


The data in the table shows that the number of the students in each grade level is not equal. However, it can be seen that the scores of higher grade level tend to be higher than the lower one. Overall, the mean score is 10.53 which can be categorized into Movers level. This indicates that the English qualification level of the participants is considered to be in the middle level.

Similar to the status of ICT subject in the primary level curriculum, it is also the school policy to decide whether English subject is included in the curriculum or not, to what grade levels it is given, and what to teach to students (Alwasilah, 2013). Students who participated in this study were all having English subject at their school. As they came from different schools, what they learned in their English classes might be different from one(s) to the others. When examining the data in Table 2, the length of time spent to learn English at school is linear with the students' grade levels. Theoretically, the higher the students' grade level, the longer they have learned English at school. Although the data of the students' English scores does not perfectly increase as the grade level got higher, the data showed the rising pattern. While the lower grade level students (2nd and 3rd graders) tended to be in the Starters levels, the higher level students (4th, 5th, and 6th graders) were likely to be in the Movers and Flyers levels.

Hence, further investigation was conducted to explore more about ICT background and English-related activities of the participants, particularly the ones that were considered anomaly, to know the underlying factors that contribute to their ICT and English competency.

\section{Participants' Perceptions towards the Online Test}

It has been explained before that the test which consisted of four parts covering listening, reading and writing skills had 20 multiple-choice questions which were compulsorily to be answered. It is interesting to know that each student differed towards which part was their preference and the reason why they liked it. In addition, which part they disliked most was also investigated. 10 out of 17 opted for Listening Part 1 as their favorite as it was the easiest of all. It solely required them to choose one pictures out of three which matched the descriptions given by the speaker. No oneof all the participants mentioned to dislike this part. The second part was Listening Part 2 that required the test takers to match the pictures and the names of the day the activities in the pictures were conducted. Although it was considered difficult by five students but there were four who enjoyed doing this part. Students who hated this part said that the speaker spoke too fast and they could not catch the words. In the contrary, students who were keen on having this part said that it was exciting having this part 
because they had learned the name of the days before. While there were eight students who were not fond of having Reading and Writing Part 3 for it involved grammar and new vocabulary, one student opted for it as her favorite. It was a completion task with five blanks in a paragraph needed to be filled in and three alternative answers were given in each number. Two students preferred Reading \& Writing Part 4. On the other hand, four found difficulties in doing this part. In these sections, participants had to complete the conversation between two people. The options for the answers were provided so that they just needed to drag the answers they chose to the given spaces.

From this findings, it was interesting to find out that students enjoyed having listening parts as in their English class at school, listening activities were rarely been conducted-all said that it was their first experiences having listening exercises like the ones in Cambridge Online Test. The discoveries of students' excitement of having online test which were signed by 13 out of 17 participants $(76.47 \%)$ who declared that they preferred having online test as it gave them new experiences of having test without paper and pencil and comfortable feeling with taking test on laptop or smartphones is coherent with the findings from the previous research comprised by Way, Davis, \& Fitzpatrick (2006). Even, when the test was over, they requested for having another test if any. In English language learning context, this positive hint is essential to encourage students' English learning through technology as when students have found it interesting to learn the language using digital media, they will be motivated to study, and learning engagement and objectives can be achieved.

\section{Participants' ICT and English-related activities and Test Results}

In order to find out more about the participants' ICT and English-related activities and to what extent they may contribute to the results of the test, further investigation was undertaken by involving parents and/or caregivers of six randomly selected participants of each qualification level in Table 1 . In the interviews, questions were given to parents covering child's ICT backgrounds and English exposures. The descriptions from parents beneficially supported and verified the data gained from the interviews with the students themselves that were conducted before. The following are the elaborations of each selected participants.

Student 5. Student 5 was an 8-year-old female student who sits in the second grade at the private school in Malang City with accredited rank A. As she gained the lowest score of all, which was 0 (zero), it is worth to investigate further about her background. Although the data showed that she learned ICT and English subject at school starting from the second grade, the parents claimed that she was not really exposed to English and digital literacy 
skills at home. Coming from a low-income family, her parents admitted that they did not understand English at all and had no idea about how to support their kid to learn English at home. In terms of ICT, gaming in her parents' smartphone on weekends was the only digital exposure she had. In other words, the ICT and English lessons she obtained in the formal setting at this current grade level were the first exposures through which she gained knowledge on digital literacy and English. Thus, no wonder when her score was the lowest of all as English and ICT were new things she learned at the present time.

Student 6 . Student 6 was a second-grade male aged 9 who came from middle-high class family. He studied in a private school in Malang City which is accredited A. In his school, English subject was given from the first grade, while ICT subject was not given until he studied on the second grade. So, he had been learning English in formal education for two years and had not learned ICT formally yet. Based on his parents' information, he was exposed to English since he was 1.5 years old through the English Channel on television, like Cartoon Network. Since he was 3 years old, the parents introduced him to a tablet. He usually played games on the tablets and watched cartoons. It was later after knowing tablet, his parents introduced him to English story books when he was 4 years old. For smartphone use, the parent asserted they did not give the child a personal smartphone for himself. He could borrow from his parents' smartphone in the given time as agreed by both of them. When he was interviewed, he clearly stated that the English subject was not his favorite at school. He could not stand studying English as he got problems with the vocabulary. Hearing about this, it was not surprising that his English test score is 6 which is in the Starters level.

Student 11. Student 11 was a fifth-grade female aged 11. She came from a middle-low income family. In her daily life, she lived with her grandmother as her mother worked out of town and the father passed away. She studied in a public elementary school with accreditation A in Batu City. In a day, she could be online for more than five hours for games, social media, music, and videos. Although she spent most of her time surfing online, the lack of parental involvement had limited this student to obtain the supreme benefits of digital media access opportunity. This might impact on her obtaining score 8 on the online test that is included in the Starters/Movers level and is the lowest among the other fifthgrade-participants. Besides, it might be due to the less interest in English subject at school that she avowed to face difficulties in understanding English vocabulary and grammar.

Student 12. This 12-year-old female student was sitting on the fifth grade in a public elementary school in Pamekasan Regency, Madura Island which was accredited B. In her school, ICT subject was not in the school curriculum while English subject was given since 
the third grade. Thus, until the study was conducted, she had not yet received any formal training on ICT and had been three years of learning English at school. Moreover, as the internet connection was not stable in the Regency where she lived, youngsters usually went to cybercafé for having internet access instead of surfing online on their smartphones. This student was one of those who faced difficulties in doing the test. Although those were minor, like how to drag the answer to the given space and what next after this section, but this experience seemed to be not exciting for her. It was known from her answers that she was not interested in joining another online test if any. She also preferred having paper and pencil test because it was simpler than the online one. Nevertheless, her score was not too low. Although coming from a middle-low income family and mostly spent her time at home with the absence of parents for they went out for work, she could get score 11 which was in the Movers level. In her case, the deficiency of formal training on ICT might trigger her disinterest towards the implementation of an online test.

Student 10. Student 10 was an 11-year-old male who was in his fifth grade. He was a student of an elementary school with accreditation rank A in Batu City. Although coming from a middle-low income family, the parents who admitted being low educated had much concern for their children's education. At home, the parents allowed him to access smartphones for gaming on weekends only. For studying at home, his older sister who was a university student was given responsibility to assist him to study. His test score was 17, included in Movers/Flyers level, was the highest among the other two fifth grader participants. Besides having been exposed with English language since he was in the kindergarten and learning ICT subject at the school since he was at the second grade, the assignment from school often demanded technology use, like finding information from Google, writing it on Word and printing it. In addition, parents' role to take part in encouraging their children to study harder and expect for a better living had positively triggered the children to study and achieve well at school.

Student 4. This second-grade student was a nine-year-old female who studied in elementary school in Malang City with accreditation rank A. Coming from a middle-high income family, this student had been exposed to English and ICT since she was a baby. Being one of the youngest of all participants, she successfully achieved the highest score in the test among others as shown in Table 2. The data discovered that home-learning-environment had been created by the parents, such as by having regular bedtime English stories reading both from e-books and printed ones, decorating walls with English words and pictures, using tablets to have interactive English games and watching cartoons which were mostly in 
English. Additionally, the information from her parent also revealed that as she liked drawing, she was exposed to use the applications on tablets for drawing and making comics and digital storybooks. So far, she had been creating pictures and producing many digital storybooks that she made and saved on her tablets and iPad. Besides the disclosures of her parents who were both academicians, from the collected information, it can be concluded that the intense exposures of both English and ICT, and parents' involvement and supports for home learning activities have positively influenced child's English and ICT competencies.

The more elaborate explorations towards those five students above have led to the findings which are parallel to those revealed by Vandoninck et al., (2010) that in terms of the online opportunities, students from higher socio-economic families have better quality of access to the internet that enables them to go online more frequently and earn more benefits from the digital technology use. However, the roles of exposure (Spolsky, 1998) of both ICT and English are particularly powerful to support students' ICT and English skills when it is with parents' involvement and guidance. In a similar vein, Kurnia \& Astuti (2017) stated that besides schools and communities, parents' roles are essential to be the role models, to guide and to get actively involved in children's digital media access. They recommended that to ensure children to use the digital media appropriately, parents need to formulate and make an agreement on how the family accesses the digital media. With the proper guidelines, negative impacts of the digital media use can be lessened or avoided, instead, children are encouraged to offer ideas on various digital literacy activities and gain experience in digital literacy so they can become agents who would bring positive impact in their communities.

\section{CONCLUSION}

Through the descriptions of elementary school students' first experiences with the technology-based test, how young learners perceived the implementation of an online test was able to be highlighted. As all of the participants $(n=17)$ took the online test for the first time, it was interesting to find out that 13 out of 17 participants $(76.47 \%)$ preferred having online test as it gave them new experiences of having test without paper and pencil and comfortable feeling with taking test on laptop or smartphones. The study that involved students of Grade 2 to 6 from three areas in East Java which were Malang City, Batu City, and Pamekasan Regency, found out that six students did not formally obtain an education on ICT. However, the data showed that there were no sizeable challenges faced by the participants as they have been possessing the basic skills and competence of ICT 
(McLoughlin, 2011). It was proved by their ICT-related activities, like gaming (88.24\%), using social media and downloading music and videos $(64.71 \%)$, searching information on Google $(41.18 \%)$, and reading e-book which was the least of all (17.65\%).

Moreover, further study was conducted to investigate to what extent the ICT backgrounds and English exposures correlated to students' online English test achievement. From the findings, it can be implied that the roles of exposure (Spolsky, 1998) of both ICT and English are positively influential to support students' ICT and English skills if, besides school, parents are actively involved to support and guide children in their home-learning activities as recommended by Meisani (2018).

Hence, in order to find out more about how ICT and English-related activities impact to young learners' ICT and English skills, further research needs to be undertaken involving a larger number of participants, so that various dimensions to support students in becoming technologically literate, particularly in relation to English language learning, can be identified. Finally, there must be collaboration among parents, school, and community, to provide opportunities for digital literacy practices to students so that they can become agents who would bring good influences in their societies.

\section{Acknowledgment}

This research is fully supported by Indonesia Endowment Fund for Education (LPDP), the Ministry of Finance of Indonesian Republic.

\section{REFERENCES}

Alabi, D., Issa, D. A. O.,\& Oyekunle, R. A. (2012). The use of computer-based testing method for the conduct of examinations at the University of Ilorin. International Journal of Learning and Development, 2(3). https://doi.org/10.5296/ijld.v2i3.1775

Alwasilah, A. C. (2013). Policy on foreign language education in Indonesia. International Journal of Education, 7(1). DOI: http://dx.doi.org/10.17509/ije.v7i1.5302

Australians, U., \& Smith, J. (2012). Beneath the " digital native " myth online time use, 49(1), 97-118. https://doi.org/10.1177/1440783311434856

Bailey, A. L. (2005). Test review.Language Testing, 22(2), 242-252. Retrieved from https://journals.sagepub.com/doi/pdf/10.1177/026553220502200206

Bangou, F.,\& Waterhouse, M. (2008). On 'becoming' technologically literate : a multiple literacies theory perspective, 5(4), 445-456.

Bittman, M., Rutherford, L., \& Brown, J. (2011). Old media and children's outcomes, 55(2), 161-175. https://doi.org/10.1177/000494411105500206Chapelle, C. A. (2003). English 
Language Learning and Technology: Lectures on Teaching and Research in the Age of Information and Communication. Amsterdam: John Benjamins Publishing.

Creswell, J. W. (2013). Research design: Qualitative, quantitative, and mixed methods approaches. https://doi.org/10.1007/s13398-014-0173-7.2

Friedrich, S. (2008). Quality features of TC Exam: An open source computer-based assessment software. Towards a research agenda on computer-based assessment. http://www.nremt.org/about/CBT.home.asp

Gupta, Nitishiree. (2018). Differences between CBT and WBT. Retrieved April 20, 2018 from http://www.commlabindia.com

Guo, R. X., Dobson, T.,\& Petrina, S. (2008). Digital natives, digital immigrants: An analysis of age and ICT competency, 38(3), 235-254. https://doi.org/10.2190/EC.38.3.a

Hamied, Fuad Abdul. (2017). Research Methods: A Guide for First Time Researchers. Bandung: UPI Press.

ICT Literacy Panel. (2002). Digital transformation: A framework for ICT literacy. A Report of the International ICT Literacy Panel. Educational Testing, 1. Retrieved from http://www.ets.org/research/ictliteracy

Killian, J. N. (2011). The Teaching/Learning of Digital Natives. https://doi.org/10.1177/1057083711414393

Kurnia, N., \& Astuti, S. I. (2017).Researchers find Indonesia needs more digital literacy education. http://theconversation.com/id/who-we-are

Luecht, R. M., \&Sireci, S. G. (2011). A review of models for computer-based testing, (1), 156. Research Report. https://files.eric.ed.gov/fulltext/ED562580.pdf

Malik, R. S.\&Hamied, F. A. (2016). Research Method: A Guide for First Time RESEARCHERS. Bandung: UPI Press.

McLoughlin, C. (2011). What ICT-related skills and capabilities should be considered central to the definition of digital literacy? In T. Bastiaens\& M. Ebner (Eds.), Proceedings of ED-MEDIA 2011--World Conference on Educational Multimedia, Hypermedia \& Telecommunications (pp. 471-475). Lisbon, Portugal: Association for the Advancement of Computing in Education (AACE). Retrieved June 5, 2018 from https://www.learntechlib.org/primary/p/37908/.

Meisani, D. R. (2018). 'Read-to-me' story book: Parent-children home reading activities. In S. Madya, F. A. Hamied, W. A. Renandya, C. Coombe, \& Y. Bhastomi (Eds). ELT in Asia in the digital era: Global citizenship and identity. London: Routledge. Retrived from VitalSource Bookshelf.

Miller, H. (2017). The myth of “digital native” generation. eLearningInside.com

Prensky, M. (2001). Digital natives, digital immigrants. NCB University Press, 9(5), 1-6.

Reed W. M., \&Giessler, S. F. (2002). Prior computer-related experiences and hypermedia metacognition. Computers in Human Behavior, 11(3-4), 581-600. https://www.sciencedirect.com/science/article/pii/0747563295800184 
Kurnia, N. \& Astuti, S. I. (2017. Researchers find Indonesia needs more digital literacy education. Retrieved from http://theconversation.com/researchers-find-indonesia-needsmore-digital-literacy-education-84570

Spolsky, Bernard. 1998. Conditions for learning English as a second language. New York: Oxford University Press.

Teo, T. (2013). 'Digital nativity': A definitional framework. World Journal on Educational Technology, 389-394. https://www.academia.edu/8279277/_Digital_Nativity_A_definitional_framework

UCLES. (2003). Cambridge Young Learners' English Tests Handbook: Starters, Movers and Flyers. Cambridge: UCLES. Available at http://www.cambridgeesol.org/support/dloads/yle/yle_hb_03.pdf

Vandoninck, S., Haenens, L. D., \& Donoso, N. (2010). Digital literacy of Flemish youth : How do they handle online content risks? 1, 35. https://doi.org/10.1515/COMM.2010.021

Way, W. D., Davis, L. L., \& Fitzpatrick, S. (2006). Score comparability of online and paper administrations of the Texas assessment of knowledge and skills. Annual Meeting of the National Council on Measurement in Education. Retrieved on May 7, 2018 from http://www.pearsonassessments.com/hai/images/tmrs/Score_Comparability_of_Online_a nd_Paper_Administrations_of_TAKS_03_26_06_final.pdf

Williams, F., Philip, L., Farrington, J., \& Fairhurst, G. (2016). 'Digital by default' and the 'hard to reach': Exploring solutions to digital exclusion in remote rural areas. https://doi.org/10.1177/0269094216670938

Zevenbergen, R., \& Zevenbergen, R. (2007). Digital natives come to preschool : Implications for early childhood practice, 8(1), 19-29. https://doi.org/10.2304/ciec.2007.8.1.19 